\title{
A Study of Injuries and Violence Related Articles in Nepal
}

\author{
Joshi SK,' Shrestha S² \\ 'Department of Community Medicine, Kathmandu Medical College, ${ }^{2}$ Kakani Primary Health Centre, Ranipauwa
}

\section{ABSTRACT}

Introduction: Nepal lacks sufficient data on injury and violence. Studies have been done in different regions but there is not a nationwide study on this topic. So, we have designed this systematic review to get a cumulative picture of injury and violence status in Nepal.

Methods: We searched Medline database, Google scholar database and also all the national medical journals for relevant studies on injuries and violence. Our eligibility criteria included studies done in Nepal, evaluating the incidence of different forms of injuries, and their causes and effects. We excluded case reports, editorials and reviews. All together, we had 23 studies. We made cumulative analysis wherever possible.

Results: All the studies were descriptive. In overall, the incidence of injuries was twice as common in male as in female with the ratio of 2.1:1. The economically active population between 20-50 years of age was mostly involved in injuries. Road traffic injuries were the most common form of injuries, most of which $(42.5 \%)$ involved motorcycles. Pedestrians $(48.6 \%)$ were the most vulnerable group of population. Falls $(48.9 \%)$ were the most common cause of neuro traumatic accidents.

Conclusions: Our systematic review suggests that injuries and violence pose a big problem; road traffic accidents make the most part of it.

Key Words: burn, falls, injury, ocular trauma, road traffic accident

\section{INTRODUCTION}

Injury and violence are one of the major public health problems, which are equally prevalent in every corner of the world. More than five million deaths per year, which makes around $9 \%$ of the global mortality, are attributed to Injury and violence. Likewise, eight of the fifteen leading causes of deaths in the age group 15-25 are injury related. Traffic crashes are the number one cause of death for children and youth between ages 10 and
24 years. About 1.2 million people die every year as a result of road traffic crashes - up to 50 million more are injured or disabled. Similarly, every year over 300000 people die from fire-related burns. ${ }^{1}$

A very few researches have been published in Nepalese medical journal related to injury. Therefore, this study aims to review those literatures on injuries and violence in our scenario.

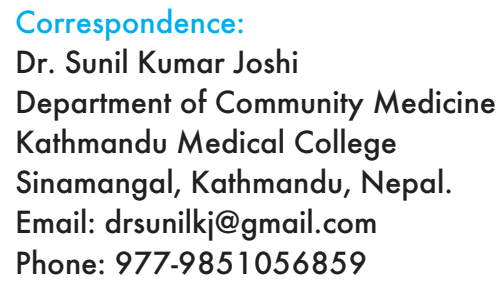




\section{METHODS}

A systemic review of injury related article published in the Nepalese medical journal was conducted. We searched databases like PubMed, and Google Scholar for all the relevant publications using keywords such as Injury, Nepal, trauma, burn, and road traffic accidents (RTA), emergency. We also searched national journals for any relevant work that were not listed in PubMed. Besides, we also consulted experts studying epidemiology of injury and violence in Nepal. To ensure complete search, we also reviewed the reference lists of all the identified studies.

Altogether we found 120 articles, of which we went through the abstracts. Many of them included case reports, reviews, and editorials. We excluded them from our study and we were left with 48 studies. We went in details of the rest of the articles, and we included only those articles which focused on the evaluation of incidence of different forms of injuries, their causes, and effects and associated factors. There were 25 studies which evaluated the efficacy of some kind of interventions in the proper management and harm limitation of injuries. We also excluded them from our study. Thus, we had 23 articles selected for the review. Three of the studies were based on school and they interviewed healthy students and they looked into how many of them had got injured in the past one year. For the evaluation in our study, we used only the number of those students who had the history of injury and not the total number of students.

For proper quality assessment of the articles included in the study, we set seven evaluative characteristics (Table 1). Two investigators, blinded to the authors, assessed those quality characteristics individually. The scores were then compared and discussed to establish a final consensual score. Besides the scores, subjective judgment of the studies was also valued for the final quality assessment.
On the basis of the score, the quality of the individual study was evaluated as good quality (score more than 12), fair quality (score in between 8-12), poor quality (score less than eight).

Wherever the data presentation is similar, we tabulated them to make a good comparison and have an overall view. There were some variables like age groups of injured ones, causes of injuries, which were assessed and presented in different forms in different articles, we either reported them separately or left them if they were not a major finding. There were some articles which focused more on road traffic accidents, and likewise, there were some other articles which focused more on neurotrauma, or burn. So, we evaluated those articles in different groups - all articles on road traffic accidents in one group, all articles on burn in another group and so on.

\section{RESULTS}

All 23 studies were observational descriptive studies, many of them based on hospital settings. Twelve studies were about the incidence of different forms of injuries and RTA. Six were more focused on neuro trauma cases including craniofacial and spinal injuries, two on ocular injuries, two on burns, and one on occupational injuries.

From all the studies, it seemed that males are more prone to get injuries than the females, as the cumulative data showed a ratio of male to female as $2.1: 1$. Sixteen studies looked into the sex distribution of the injuries; the total number adds up to 15768 cases of injuries. Out of them, $10685(67.8 \%)$ were male which is more than twice the number of females 5083 (32.2\%). Though there were minor differences in the study settings, none of the studies show higher incidence of injuries among females.

We also found that most of the injured ones belonged to the economically active population (Table 3 ), which adds to the economic burden of the injuries being unable to go to work.

\section{Table 1. Quality assessment variables}

\begin{tabular}{lll}
\hline SN & Characteristics & Description and scores \\
\hline 1. & Study design & 1. Retrospective, 2. Prospective \\
2. & Study setting & 1. Hospital-based, 2. Community based \\
3. & Sampling & 1. Convenient sampling, 2. Random sampling \\
4. & Sample size & 1. Less than $500,2.500$ to 1000, 3. more than 1000 \\
5. & Potential for selection bias & 1. Large, 2. Moderate, 3. Small \\
6. & Potential for information bias & 1. Large, 2. Moderate, 3. Small \\
7. & Quality of reporting & Subjective assessment (1. Poor, 2. Fair, 3. Good) \\
\hline
\end{tabular}


Table 2. Studies and their description

\begin{tabular}{|c|c|c|c|c|c|c|}
\hline \multicolumn{7}{|c|}{ Studies on Road traffic accidents } \\
\hline SN & Author & Design & Setting & Sample & Outcome measures & Quality \\
\hline 1. & Joshi et $\mathrm{al}^{2}$ & $\begin{array}{l}\text { Observational } \\
\text { descriptive study }\end{array}$ & $\begin{array}{l}\text { Hospital based } \\
\text { study }\end{array}$ & 505 & $\begin{array}{l}\text { Incidence of different forms } \\
\text { of injuries, their economic } \\
\text { burden }\end{array}$ & Good \\
\hline 2. & Meskin et $\mathrm{al}^{3}$ & $\begin{array}{l}\text { Retrospective } \\
\text { descriptive study }\end{array}$ & Hospital based & $\begin{array}{l}737 \text { cases } \\
\text { reported } \\
\text { in ED ( } 220 \\
\text { injury cases) }\end{array}$ & $\begin{array}{l}\text { Services provided by } \\
\text { emergency department (ED) } \\
\text { and the different types of } \\
\text { injuries recorded in ED }\end{array}$ & Good \\
\hline 3. & Banthia et $\mathrm{al}^{4}$ & $\begin{array}{l}\text { Retrospective } \\
\text { descriptive study }\end{array}$ & Hospital based & 757 & $\begin{array}{l}\text { Incidence of RTAs, Vehicles } \\
\text { involved, type of injuries }\end{array}$ & Good \\
\hline 4. & Jha et $a^{5}$ & $\begin{array}{l}\text { Observational } \\
\text { descriptive study }\end{array}$ & Hospital based & 870 & $\begin{array}{l}\text { Different types of RTA } \\
\text { injuries, vehicles involved, } \\
\text { nature of injuries }\end{array}$ & Good \\
\hline 5. & Sharma et $a^{6}$ & $\begin{array}{l}\text { National census } \\
\text { survey }\end{array}$ & $\begin{array}{l}\text { Community } \\
\text { based survey }\end{array}$ & 7010 & $\begin{array}{l}\text { Causes of deaths in } \\
\text { community }\end{array}$ & Good \\
\hline 6. & $\begin{array}{l}\text { Poudel Tandukar } \\
\text { et } \mathrm{al}^{7}\end{array}$ & Descriptive study & $\begin{array}{l}\text { School based } \\
\text { survey }\end{array}$ & 1557 & $\begin{array}{l}\text { Activities during and } \\
\text { mechanism of pedestrian } \\
\text { injury }\end{array}$ & Good \\
\hline 7. & Agnihotri et $\mathrm{al}^{8}$ & $\begin{array}{l}\text { Observational } \\
\text { study }\end{array}$ & Hospital based & 217 & $\begin{array}{l}\text { Incidence of RTAs, causes, } \\
\text { types of injuries }\end{array}$ & Moderate \\
\hline 8. & $\begin{array}{l}\text { Poudel Tandukar } \\
\text { et } \mathrm{al}^{9}\end{array}$ & $\begin{array}{l}\text { Observational } \\
\text { study }\end{array}$ & School based & 1557 & $\begin{array}{l}\text { Risk perception, road } \\
\text { behavior and pedestrian } \\
\text { injuries }\end{array}$ & Good \\
\hline 9. & $\begin{array}{l}\text { Poudel Tandukar } \\
\text { et } \mathrm{al}^{10}\end{array}$ & $\begin{array}{l}\text { Secondary data } \\
\text { analysis }\end{array}$ & $\begin{array}{l}\text { Traffic police } \\
\text { report }\end{array}$ & $\begin{array}{l}\text { Traffic } \\
\text { police } \\
\text { data from } \\
1981 / 82- \\
2002 / 03\end{array}$ & $\begin{array}{l}\text { Trend in the number of } \\
\text { RTA deaths }\end{array}$ & Moderate \\
\hline 10. & $\begin{array}{l}\text { Poudel Tandukar } \\
\text { et } \mathrm{al}^{11}\end{array}$ & $\begin{array}{l}\text { Observational } \\
\text { study }\end{array}$ & School based & 1557 & $\begin{array}{l}\text { Different forms of injuries } \\
\text { and their mechanism }\end{array}$ & Good \\
\hline 11. & Sharma $\mathrm{G}$ et $\mathrm{al}^{12}$ & $\begin{array}{l}\text { Retrospective } \\
\text { review }\end{array}$ & $\begin{array}{l}\text { Post mortem } \\
\text { reports }\end{array}$ & $\begin{array}{l}4383 \\
\text { postmortem } \\
\text { cases ( } 2850 \\
\text { traumatic } \\
\text { deaths) }\end{array}$ & $\begin{array}{l}\text { Different causes of } \\
\text { traumatic deaths }\end{array}$ & Good \\
\hline 12. & Ghimire $A$ et al $^{13}$ & $\begin{array}{l}\text { Cross sectional } \\
\text { study }\end{array}$ & $\begin{array}{l}\text { Community } \\
\text { based survey }\end{array}$ & 299 & $\begin{array}{l}\text { Different forms of injuries } \\
\text { and their mechanism }\end{array}$ & Moderate \\
\hline \multicolumn{7}{|c|}{ Studies on Neurotrauma } \\
\hline 13. & Agrawal et al ${ }^{14}$ & $\begin{array}{l}\text { Retrospective } \\
\text { descriptive study }\end{array}$ & $\begin{array}{l}\text { Hospital based } \\
\text { study }\end{array}$ & 334 & $\begin{array}{l}\text { Cause and nature of the } \\
\text { trauma }\end{array}$ & Good \\
\hline 14. & Bajracharya et al ${ }^{15}$ & $\begin{array}{l}\text { Retrospective } \\
\text { descriptive study }\end{array}$ & $\begin{array}{l}\text { Hospital based } \\
\text { analysis }\end{array}$ & 896 & $\begin{array}{l}\text { Cause and nature of the } \\
\text { trauma }\end{array}$ & Good \\
\hline 15. & Agnihotri et al ${ }^{16}$ & $\begin{array}{l}\text { Retrospective } \\
\text { descriptive study }\end{array}$ & $\begin{array}{l}\text { Hospital based } \\
\text { analysis }\end{array}$ & 170 & Cause and nature of injury & Moderate \\
\hline 16. & Shrestha et al ${ }^{17}$ & $\begin{array}{l}\text { Prospective } \\
\text { observational } \\
\text { study }\end{array}$ & Hospital based & 149 & $\begin{array}{l}\text { Etiology, methods, hospital } \\
\text { management and recovery }\end{array}$ & Good \\
\hline 17. & McClennan et al ${ }^{18}$ & $\begin{array}{l}\text { Retrospective } \\
\text { descriptive study }\end{array}$ & Hospital based & 283 & Cause and nature of injury & Moderate \\
\hline 18. & Mukhida et al $^{19}$ & $\begin{array}{l}\text { Retrospective } \\
\text { descriptive study }\end{array}$ & Hospital based & 352 & Cause and nature of injury & Moderate \\
\hline \multicolumn{7}{|c|}{ Studies on Burn } \\
\hline 19. & Shrestha SR ${ }^{20}$ & $\begin{array}{l}\text { Prospective } \\
\text { descriptive study }\end{array}$ & Hospital based & 20 & $\begin{array}{l}\text { Types of burn, outcome of } \\
\text { burn }\end{array}$ & Moderate \\
\hline 20. & Liu et $\mathrm{al}^{21}$ & $\begin{array}{l}\text { Prospective } \\
\text { descriptive study }\end{array}$ & Hospital based & 237 & $\begin{array}{l}\text { Nature of burn, age and sex } \\
\text { distribution, severity }\end{array}$ & Good \\
\hline
\end{tabular}




\section{Study on occupational injury}

21. Pokharel et $\mathrm{a}^{22} \quad \begin{aligned} & \text { Prospective } \\ & \text { descriptive study }\end{aligned}$ Hospital based $100 \quad \begin{aligned} & \text { Types of occupational } \\ & \text { injuries, age distribution, } \\ & \text { risk factors, type of injuries }\end{aligned} \quad$ Moderate

\section{Studies on Eye injuries}

\begin{tabular}{|c|c|c|c|c|c|}
\hline 22. Adhikari et $\mathrm{al}^{23}$ & $\begin{array}{l}\text { Retrospective } \\
\text { descriptive study }\end{array}$ & Hospital based & $\begin{array}{l}3284 \\
\text { traumatic } \\
\text { cases out of } \\
5504 \text { total } \\
\text { lesions }\end{array}$ & $\begin{array}{l}\text { Causes and types of eye } \\
\text { injuries, treatments and } \\
\text { outcomes }\end{array}$ & Good \\
\hline 23. Khatry et $\mathrm{al}^{24}$ & $\begin{array}{l}\text { Prospective } \\
\text { study }\end{array}$ & Hospital based & 525 & $\begin{array}{l}\text { Incidence and type of } \\
\text { ocular injuries, treatments }\end{array}$ & Good \\
\hline
\end{tabular}

Table 3. Age distribution of the injury cases

\begin{tabular}{|c|c|c|c|}
\hline SN & Study & $\begin{array}{l}\text { Commonest } \\
\text { age group } \\
\text { involved in } \\
\text { injury }\end{array}$ & Number (\%) \\
\hline 1. & Jha et $\mathrm{al}^{5}$ & $21-30$ & $249(28.6)$ \\
\hline 2. & Shrestha et al $^{17}$ & $41-50$ & 35 (23) \\
\hline 3. & Agrawal et $\mathrm{al}^{14}$ & $21-30$ & $70(20.4)$ \\
\hline 4. & Banthia et $\mathrm{al}^{4}$ & $21-30$ & 257 (33.9) \\
\hline 5. & Agnihotri et $\mathrm{al}^{8}$ & $15-30$ & $106(48.8)$ \\
\hline 6. & Agnihotri et al $^{16}$ & $15-30$ & 77 (45.3) \\
\hline 7. & Khatry et $\mathrm{al}^{24}$ & $21-30$ & $130(24.8)$ \\
\hline 8. & Adhikari et $\mathrm{al}^{23}$ & $15-50$ & $41(41)$ \\
\hline 9. & McClennan et $\mathrm{al}^{18}$ & $21-45$ & $155(52.5)$ \\
\hline 10. & Liu et $\mathrm{al}^{21}$ & $15-60$ & 85 (35.9) \\
\hline 11. & Bajracharya et al ${ }^{15}$ & $50-70$ & $246(27.5)$ \\
\hline 12. & Joshi et al $^{2}$ & $21-55$ & $303(60)$ \\
\hline
\end{tabular}

Twelve reports were found which described the incidence and causes of injuries, focusing more on road traffic accidents (Table 2). Three of them were school based, which interviewed the school children on their knowledge, opinion and experiences with injuries. ${ }^{7,9,11}$ One of the studies was a part of National census; it looked into the data from community and evaluated different causes of death in community. ${ }^{6}$ Likewise, one study looked into the data from the Traffic police and traced the trend in the rise of RTA deaths in nearly two decades. ${ }^{10}$ Another one was a four year retrospective study of post-mortem cases and looked into the different causes of traumatic deaths. ${ }^{12}$ The other was a community based study, which interviewed people in the community about the history of injuries in their families. ${ }^{13}$ The rest were hospital based surveys (Table 2).
There were three studies which surveyed different modes of injuries. Joshi et al found RTIs as the most common mode of injury 214 (42\%), followed by work injuries $93(18.5 \%)$, and playing sports $76(15.1 \%){ }^{2}$ However, Poudel-Tandukar et al found fall from height as the most common mode of injury 1017 (65\%), followed by Domestic injuries, cuts etc 974 (63\%) and finally transport related injuries 563 (36\%). ${ }^{11}$ Likewise, Ghimire et al also reported falls as the most common mode of injury 104 (34.8\%), followed by cuts and stabs $84(28.1 \%)$, and finally RTIs 45 (15.1\%). ${ }^{13}$ However, the major difference between the studies is Poudel-Tandukar's study is a school based study which interviewed the students about their experience of most severe injury in the last 12 months. Likewise, Ghimire's study is a community based study which interviewed the people about their experience of injuries in the last 12 months. Whereas Joshi's is a hospital based observational study which recorded all the injury cases which were reported to the emergency department of the hospital.

Likewise, there was one retrospective study which analyzed different modes of deaths in a post mortem centre. Sharma et al looked into 4383 post mortem reports, among them, 1403 (32\%) were accidents, 1095 (25\%) were suicides, 394 (9\%) were homicides, $614(14 \%)$ were natural medical diseases, and 920 (21\%) were undetermined. Altogether, there were 2850 cases of traumatic deaths. Out of them, RTIs were the commonest cause 772 (27\%), followed respectively by hanging 591 (20.7\%), poisoning $223(7.8 \%)$, burn 209 $(7.3 \%)$, firearm injuries 185 (6.5\%), falls 168 (5.9\%), and others. ${ }^{12}$

Five studies evaluated the different forms of injury sustained due to trauma (Table 4).

In overall, open wounds including incised and lacerated ones constitute the most common form of injury, followed by abrasions, contusions and then fractures and dislocation of joints. 
Five studies evaluated the involvement of different types of vehicles in the road traffic accidents (Table 5).

These all studies have unanimously found the high prevalence of motorcycle involvement in RTIs. The total probability of motorcycle being involved in a RTA comes to $42.5 \%$, while no other vehicle crosses even $30 \%$ of probability.

Five studies looked into the most vulnerable group of population to get involved in a RTA (Table 6).

So, the pedestrians seem to be at the highest risk of getting involved in RTA with a probability of $48.6 \%$. Jha et al and Joshi et al didn't categorize the pillion rider and passenger as separate entities.

Two of the studies looked into which organ is most commonly injured in a RTA. Banthia et $\mathrm{al}^{4}$ found the highest involvement of limbs while Agnihotri et al found head to be injured the most. ${ }^{8}$

Likewise Banthia et al and Jha et al also looked into the seasonal variation in the incidence of RTAs, however, their findings differ from each other. Banthia has found most injuries occur in April - May while Jha et al reported July to be the month with most injuries. However, these all months fall in summer and rain, which shows the high incidence of injuries during the summer.

Many studies have not looked into the possible role of alcohol use in the RTA, while it's highly reasonable that driving under the influence of alcohol increases the risk of accidents. Jha et al found that among the 212 injured drivers, 36 (16.9\%) had consumed alcohol, while Agnihotri et al also found that $10(17.2 \%)$ out of

Table 4. Different forms of injuries sustained

\begin{tabular}{llllllll}
\hline SN & Study & Open wounds & $\begin{array}{l}\text { Soft tissue } \\
\text { injuries }\end{array}$ & $\begin{array}{l}\text { Fractures and } \\
\text { dislocation }\end{array}$ & $\begin{array}{l}\text { Abrasion and } \\
\text { contusions }\end{array}$ & $\begin{array}{l}\text { Head injury } \\
\text { Internal organ } \\
\text { injury }\end{array}$ \\
\hline 1. & Joshi et $\mathrm{al}^{2}$ & $245(40.2 \%)$ & $56(9.2 \%)$ & $130(21.3 \%)$ & $102(16.7 \%)$ & $24(3.9 \%)$ & $11(1.8 \%)$ \\
2. & Meskin et $\mathrm{al}^{3}$ & $71(32.2 \%)$ & & $69(31.3 \%)$ & $23(10.5 \%)$ & $11(5 \%)$ & $2(1 \%)$ \\
3. & Banthia et $\mathrm{al}^{4}$ & $209(19.9 \%)$ & $305(29.1 \%)$ & $177(16.9 \%)$ & $348(33.1 \%)$ & $10(0.9 \%)$ \\
4. & $\begin{array}{l}\text { Poudel-Tandukar } \\
\text { et al }{ }^{11}\end{array}$ & $251(70.3 \%)$ & $50(14.0 \%)$ & $8(2.2 \%)$ & $48(13.4 \%)$ & \\
5. & Sharma et al ${ }^{12}$ & $912(32 \%)$ & & $713(25 \%)$ & $2195(77 \%)$ & $827(29 \%)$ \\
\hline
\end{tabular}

Table 5. Different types of vehicles involved in accidents

\begin{tabular}{|c|c|c|c|c|c|c|}
\hline SN & Study & $\begin{array}{l}\text { Bicycles, } \\
\text { rickshaw }\end{array}$ & Motorcycles & $\begin{array}{l}\text { Light four wheelers } \\
\text { like cars, tempo }\end{array}$ & $\begin{array}{l}\text { Heavy four wheelers } \\
\text { like trucks, buses }\end{array}$ & Others \\
\hline 1. & Banthia et $\mathrm{al}^{4}$ & $73(9.6 \%)$ & $417(55.1 \%)$ & $129(17.04 \%)$ & $87(11.5 \%)$ & $51(6.7 \%)$ \\
\hline 2. & Joshi et $\mathrm{al}^{2}$ & $12(6.8 \%)$ & $115(64.9 \%)$ & $26(14.7 \%)$ & $20(11.3 \%)$ & $3(2.3 \%)$ \\
\hline 3. & Jha et $\mathrm{al}^{5}$ & $104(11.2 \%)$ & $237(25.6 \%)$ & $171(18.5 \%)$ & $404(43.7 \%)$ & $9(1 \%)$ \\
\hline 4. & Agnihotri et $\mathrm{al}^{8}$ & & $81(37.33 \%)$ & $15(6.9 \%)$ & $49(22.6 \%)$ & \\
\hline \multirow[t]{2}{*}{5.} & Poudel-Tandukar et al ${ }^{11}$ & $128(35.9 \%)$ & $153(42.9 \%)$ & $76(21.2 \%)$ & & \\
\hline & Total & $317(13.4 \%)$ & $1003(42.5 \%)$ & $977(41.4 \%)$ & & $63(2.7 \%)$ \\
\hline
\end{tabular}

Table 6. Different groups of population involved in accidents

\begin{tabular}{llllll}
\hline SN & Study & Pedestrian & Driver/Front rider & Pillion rider* $^{*}$ & Passenger* $^{*}$ \\
\hline 1. & ${\text { Banthia et } \mathrm{l}^{4}}^{4}$ & $428(56.5 \%)$ & $191(25.4 \%)$ & $39(5.2 \%)$ & $48(6.4 \%)$ \\
2. & Jha et $\mathrm{l}^{5}$ & $257(29.6 \%)$ & $212(24.4 \%)$ & $400(46 \%)$ & $120(23.9 \%)$ \\
3. & Joshi et $\mathrm{al}^{2}$ & $180(35.7 \%)$ & $182(36.3 \%)$ & $23(10.6 \%)$ & $139(18 \%)$ \\
4. & Agnihotri et $\mathrm{al}^{8}$ & $72(33.2 \%)$ & $58(26.7 \%)$ & & $\mathbf{7 6 9 ( 2 6 . 3 \% )}$ \\
5. & Sharma et al ${ }^{12}$ & $486(63 \%)$ & $93(12 \%)$ & $\mathbf{7 3 6 ( 2 5 . 1 \% )}$ & \\
\hline
\end{tabular}

*Pillion riders and passengers are grouped into a single category as some authors didn't consider them as different entities. 
58 motor cycles riders who got injured had consumed alcohol. So, alcohol consumption is also one of the major factors that could explain high incidence of road traffic injuries.

One study looked into the risk perception among the adolescents on road traffic injuries. ${ }^{9}$ Poudel-Tandukar et al reported that those who acknowledged that they don't always look both ways or don't wait for green signals were more likely to sustain a pedestrian injury. Those who perceived it to be safe to cross roads at any part were less likely to look both ways before crossing the roads. So, they concluded that people's perception and attitude towards roads safety could be a very important aspect in controlling road traffic accidents.

Only one study reported the status of emergency services in Kathmandu valley. ${ }^{3}$ This study was done back in 1990s, so, it not might reflect the present status correctly. But it reported that emergency departments are usually open wards with 10-15 trolleys, with often poor lightening, with only medical graduates to handle all the cases and general practitioners available only during the day as back up. Nurses, health assistants do the majority of emergency services including dressing, stitching wounds etc. Emergency driver have no medical training. However, emergency departments are equipped with supplementary oxygen, electronic monitors, defibrillators, airway management kits, electrocardiography machines. However, the emergency settings are still the same in most of the hospitals. So, this study seems appropriate and it describes the emergency services in our hospitals.

Six studies specially looked into different forms of neuro trauma (Table 2). In total, fall from height 1059 (48.9\%) was found to be the most common cause of neuro trauma in Nepal, followed by road traffic accidents 604 (27.9\%) (Table 7). There were numerous minor causes as well which have been accumulated under the term others, they include farm injuries, being hit by animals, sports injuries, being hit by a falling object and fire arm injuries. But these were minor and could not be included for the cumulative analysis.
The studies had varied measures for the assessment of nature and severity of injury. Two studies evaluated the severity in terms of American Spinal Injury Association (ASIA) impairment scale. Mukhida et al found that majority 102 (29\%) of the neuro-traumatic cases in his study belonged to grade $D$, followed by grade $A$ and E (both $85(24 \%))$. Whereas, Bajracharya et al found that majority of the cases fall in grade A 302 (34\%), followed by grade E 239 (27\%). However, it has to be considered that Mukhida et al did his study on paediatric population.

Mukhida et al and McClennan et al both used Glasgow Coma Scale (GCS) to assess the severity of injury. They both found that majority $281(58 \%)$ of the cases were mild injuries (GCS score 13-15), followed by moderate (GCS 8-12) 136 (28\%) and mild cases (GCS < 8) 67 $(14 \%)$. Likewise, Shrestha et al used Frankel grading system for the assessment.

Three studies also looked into the number of hours elapsed before the injured one could get medical help. Two of them (Shrestha et al and Bajracharya et al) found the average injury hospital duration to be 43.8 and 41.6 hours respectively while McClennan et al found it to be 15.7 hours.

There were two studies which studied burns in different parts of Nepal (Table 2). Both of them are hospital based descriptive studies. Shrestha et $\mathrm{al}^{20}$ conducted a yearlong prospective study among children at a tertiary health centre while Liu et $\mathrm{al}^{21}$ did a similar study among the adults for three years in another health centre.

Liu et al reported that more than $60 \%$ of the burn cases were below 15 years of age and about $40 \%$ were below four years of age. And $76 \%$ of the cases had less than $20 \%$ of body surface area involved with a mean extent of $16.3 \%$. Likewise, house fire $93(60.8 \%)$, burns from lamps $31(20.3 \%)$, stoves $20(13.1 \%)$ were the major causes of burns. Flame burn $152(64.2 \%)$, scalds $67(28.2 \%)$, electrical burns $9(3.8 \%)$, flash burns 5 $(2.1 \%)$ and chemical burns $3(1.3 \%)$ were the major types of burns. Out of 234 reported cases, 55 died

Table 7. Causes of neurotrauma

\begin{tabular}{llllll}
\hline SN & Study & Fall from height & RTA & Physical assault & Others \\
\hline 1. & Agnihotri et al ${ }^{16}$ & $14(8.2 \%)$ & $118(69.4 \%)$ & $29(17.1 \%)$ & $9(5.3 \%)$ \\
2. & McClennan et al ${ }^{18}$ & $103(36 \%)$ & $100(35.3 \%)$ & $58(20.5 \%)$ & $22(7.8 \%)$ \\
3. & Shrestha et al ${ }^{17}$ & $90(60 \%)$ & $32(22 \%)$ & $5(3 \%)$ & $22(14 \%)$ \\
4. & Mukhida et al ${ }^{19}$ & $221(63.5 \%)$ & $93(26.7 \%)$ & $6(1.7 \%)$ & $28(8.1 \%)$ \\
5. & Agrawal et al ${ }^{14}$ & $103(31.0 \%)$ & $145(43.6 \%)$ & $64(19.3 \%)$ & $20(6.0 \%)$ \\
6. & Bajracharya et al ${ }^{15}$ & $528(60.0 \%)$ & $116(12.9 \%)$ & - & $242(27.1 \%)$ \\
& Total & $1059(48.9 \%)$ & $604(27.9 \%)$ & $162(7.5 \%)$ & $343(15.7 \%)$ \\
\hline
\end{tabular}


with a mortality of $23.5 \%$. More than $50 \%$ of the dead patients had more than $30 \%$ of their body surface area burnt.

There was one study which evaluated 100 cases of industrial accident cases which were brought to the two study hospitals (Table 2). ${ }^{22}$ Most of the injuries $(66 \%)$ occurred in carpet and furniture industries. $82 \%$ of the injured workers didn't have any sort of training related to their work. Of the injured workers, $18 \%$ were working continuously for more than seven hours without rest.

There were two studies which evaluated different forms of eye injuries (Table 2). One of them is a retrospective descriptive hospital based study ${ }^{23}$ while the other is a prospective hospital based observational study. ${ }^{24}$

In total they evaluated 3809 cases. Khatry et al calculated the incidence of ocular trauma as 0.51 per 1000 people and the incidence peaked at $40-49$ years of age for both sexes. The results are quite different when compared to Adhikari et al., who found that ocular trauma peaked at $15-50$ years of age.

Both studies reported that majority of the cases came to health centre within seven days of injury. Adhikari et al. added that only $12 \%$ of the cases reported to the hospital within 24 hours.

The two studies vary mildly in the way they assessed the types of ocular injuries. Khatry et al. classified injuries as laceration $385(73.3 \%)$, blunt injuries 98 (18.7\%), penetrating injuries 26 (4.9\%), and chemical burns 7 (1.3\%). Meanwhile, Adhikari et al assessed eye injuries as simple abrasion 194 (6.3\%), simple ulcer 1156 $(37.7 \%)$, foreign body in eye $128(4.2 \%)$, perforating injury $141(4.6 \%)$, keratitis $710(23.2 \%)$, and corneal opacity $738(24 \%)$.

Khatry et al. also reported that majority of the injuries $168(32 \%)$ occured at home, $144(27.4 \%)$ in agriculture fields, $72(13.7 \%)$ in roads, $44(8.4 \%)$ in factories and the rest in construction sites.

Likewise, Adhikari et al. reported that stick and grass are the most common traumatic agents accounting for $1270(38.7 \%)$ and 952 (29\%) of the cases respectively. Other agents include grains 637 (19.4\%), foreign body $279(8.5 \%)$, physical assault $233(7.1 \%)$ and animal horns and tails $203(6.2 \%)$.

\section{DISCUSSION}

This review suggests that males are more prone towards injuries, and especially the economically active population (20-50 years of age) constitute the majority of injured ones. This is very significant because in Nepal, it's usually the male who is the key person and the only source of income in the family. The whole family suffers if he can't go to work and earn. So, with majority of injuries among the male and economically active ones, we can imagine how big and severe effect it will have. However, the age categories used were different in different studies, which made it hard to deduce an exact incidence of injury among different age groups. But, even with varying age categories used, all the studies had the same conclusions individually.

RTIs and falls were the most common form of injuries. Among the RTIs, $42.5 \%$ involved motor cycles and $48.6 \%$ of the injured ones were pedestrians. These figures should be taken with great caution because motorcycles are considered the most convenient mode of transport and the most fancied one among the youth. So, with the increasing use of this vehicle, the trend of injuries would also escalate. Thus, proper education, safety measures like use of helmets, speed limits should be strongly emphasized to the users. The other figure with the huge number of pedestrians being injured also demands that special attention be paid on road safety measures like proper foot paths, street lights, and over head bridges.

Fall from height was also found as a common mode of injury. In fact, our review found that it is the most common cause $(48.9 \%)$ of neurotrauma. Majority of the neurotrauma cases were found to be mild cases, but there were some differences between the severity scoring systems used in different studies. ASIA grading system, Frankel grading system and GCS scores were used for the severity assessment. The lack of uniformity in grading systems made it difficult to get cumulative severity scores.

We reviewed twenty three previous studies on injury conducted in Nepal, out of which 15 were considered good studies and the rest moderate quality studies according to our pre-set quality scoring system. Majority of studies included being good quality studies ensures credibility to the results and conclusions of this review.

Among the neuro traumatic injury studies, two (Shrestha et al and Bajracharya et al), reported the average injury hospital duration to be 43.8 and 41.6 hours respectively while another one (McClennan et al), reported it to be 15.7 hours. This difference could be explained by the fact that McClennan study was based in a hospital in Kathmandu, where there is easy access to hospital and there is more availability of transport, where as the other two studies are based in hospital in the eastern region of Nepal which is comparatively less developed in terms of transport facilities and health care services as well. So, people from distant places also have to come to the same health centre which will obviously take a long time. Whereas the situation is different in Kathmandu, because there are many health centres and people who are distant to the study health centre do not have to come to the same centre, they can get help in any centre which is closer to them. So, the study hospital will not get patients from distant places. 
Joshi et al. A Study of Injuries and Violence Related Articles in Nepal

Our review includes studies done in different parts of the country; some are more developed than the others. This variation in the settings of the studies could be a setback to this review as the settings make a difference in the outcome of the studies and thus it might not be suitable to merge all the data and make a comparison. Like, the nature of injuries in a rural area would definitely be different from that of the injuries in an urban area. But, we've tried not to put all the data together if the settings are different. This should even out the effect of different backgrounds of the studies included in the review.

\section{CONCLUSION}

Injury and violence, undoubtedly, are among the biggest challenges for mankind at present. It's an even bigger problem for the developing countries like Nepal. In such situation, we need a realistic picture of the situation and accordingly we have to devise appropriate control measures. Our review concludes that RTIs are very common; they mostly involve motorcycles and the pedestrians. So, the national policy makers should pay special attention to these while making road safety policies.

\section{REFERENCES}

1. WHO. 10 facts on injuries and violence. [Updated $2008 \mathrm{Mar}$ 12; cited 2008 Oct 25]. Available from: URL:http://www. who.int/features/factfiles/injuries/en/index.html

2. Joshi SK, Shrestha S. Situation Analysis to Strengthen and Establish Effective Injury Surveillance System in two districts (Kathmandu and Bhaktapur). Kathmandu: Government of Nepal - Ministry of Health and Population (MoH\&P) / World Health Organization, Nepal; 2008.

3. MeskinS, Huyler F, Gupta SK, Berger L. Delivery of emergency medical services in Kathmandu, Nepal. Ann Emerg Med. 1997;29:409-14

4. Banthia P, Koirala B, Rauniyar A, Chaudhary D, Kharel T, Khadka SB. An epidemiological study of road traffic accident cases attending emergency department of teaching hospital. J Nep Med Assoc. 2006;45:238-43

5. Jha N, Agrawal CS. Epidemiological study of road traffic accident cases: a study from eastern Nepal. Regional health forum. 2004;8(1):15-22.

6. Sharma GK. Leading causes of mortality from diseases and injury in Nepal: a report from national census sample survey Journal of institute of medicine. 2006;28(1):7-11.

7. Poudel-Tandukar K, Nakahara S, Ichikawa M, Poudel KC, Wakai S. Relationship between mechanisms and activities at the time of pedestrial injury and activity limitation among school adolescents in Kathmandu, Nepal. Accid Anal Prev. 2006;38:1058-63.

8. Agnihotri AK, Joshi HS. Pattern of road traffic injuries: one year hospital based study in western Nepal. Int J Inj Contr Saf Promot. 2006;13(2):128-30.

9. Poudel-Tandukar K, Nakahara S, Ichikawa M, Poudel KC, Jimba M. Risk perception, road behavior, and pedestrian injury among adolescent students in Kathmandu, Nepal. Inj Prev. 2007;13:258-63.

10. Poudel-Tandukar K, Nakahara S, Poudel KC, Ichikawa M, Wakai S. Traffic fatalities in Nepal. JAMA. 2004;291(21):2542.

11. Poudel-Tandukar K, Nakahara S, Ichikawa M, Poudel KC, Joshi $\mathrm{AB}$, Wakai $\mathrm{S}$. Unintentional injuries among school adolescents in Kathmandu, Nepal: a descriptive study. Public health. 2006;120:641-9.

12. SharmaG,ShresthaPK, WastiH,KadelT,GhimireP,Dhungana S. A review of violent and traumatic deaths in Kathmandu, Nepal. Int J Inj Contr Saf Promot. 2006;13(3):197-9.
13. Ghimire A, Nagesh S, Jha N, Niraula SR, Devkota S. An epidemiological study of injury among urban population. Accepted in Kathmandu Univ Med J. 2009;7(28). [in press].

14. Agrawal A, Agrawal CS, Kumar A, Lewis O, Malla G, Chalise $P$. Head injury at a tertiary referral centre in the eastern region of Nepal. East and central African journal of surgery. 2009;14(1):57-63.

15. Bajracharya S, Singh M, Singh GK, Shrestha BP. Clinicoepidemiological study of spinal injuries in a predominantly rural population of eastern Nepal: a 10 years analysis. Indian journal of orthopaedics. 2007;41(4):286-9.

16. Agnihotri AK, Joshi HS, Tsmilshina N. Study of craniofacial trauma in a tertiary care hospital, western Nepal. MedicoLegal update. 2005;5(1). [Cited 2009 Jan 1]. Available from: URL:http:/ / www.indmedica.com/journals.php?journalid=9 \&issueid $=67 \&$ articleid $=858 \&$ action $=$ article

17. Shrestha D, Garg M, Singh GK, Singh MP, Sharma UK Cervical spine injuries in a teaching hospital of eastern region of Nepal: a clinico-epidemiological study. J Nepal Med Assoc. 2007;46(167):107-11.

18. McClennan S, Snider C. Head injuries in Kathmandu, Nepal MUMJ. 2003;1(1):10-4.

19. Mukhida K, Sharma MR, Shilpakar SK. Pediatric neurotrauma in Kathmandu, Nepal: implications for injury management and control. Child Nerv Syst. 2006;22:352-62.

20. Shrestha SR. Burn injuries in pediatric population. J Nepal Med Assoc. 2006;45(163):300-5.

21. Liu EH, Khatri B, Shakya YM, Richard BM. A 3 year prospective audit of burns treated at the western regional hospital of Nepal. Burns. 1998;24:129-33.

22. Pokharel RK, Rimal N, Ojha S, Mishra A. Study on 100 industrial accident cases in Nepal: type and severity of the injuries and its predisposing factors. J Nepal Health Res Counc. 2003;1(2):19-24.

23. Adhikari RK. Analysis of corneal injuries in King Mahendra Memorial Eye Hospital, Bharatpur, Chitwan. Kathmandu Univ Med J. 2006;4(13):34-9.

24. Khatry SK, Lewis AE, Schein OD et al. The epidemiology of ocular trauma in rural Nepal. Br J Ophthalmol. 2004;88:45660. 